\title{
Executive Authority to Reform Health: Options and Limitations
}

Madhu Chugh

This paper can be downloaded free of charge from:

http://scholarship.law.georgetown.edu/ois_papers/22 


\section{Legal Solutions in Health Reform}

\section{Executive Authority to Reform Health: Options and Limitations} Madhu Chugh, JD, MPP 


\section{O’Neill Institute}

for National and Global Health Law

\section{THE LINDA D. AND TIMOTHY J. O’NEILL INSTITUTE FOR NATIONAL AND GLOBAL HEALTH LAW}

AT

GEORGETOWN LAW

The O'Neill Institute for National and Global Health Law at Georgetown University is the premier center for health law, scholarship and policy. Housed at Georgetown University Law Center, in the heart of the nation's capital, the Institute has the mission to provide innovative solutions for the leading health problems in America and globally-from infectious and chronic diseases to health care financing and health systems. The Institute, a joint project of the Law Center and School of Nursing and Health Studies, also draws upon the University's considerable intellectual resources, including the School of Medicine, the Public Policy Institute, and the Kennedy Institute of Ethics.

The essential vision for the O'Neill Institute rests upon the proposition that the law has been, and will remain, a fundamental tool for solving critical health problems in our global, national, and local communities. By contributing to a more powerful and deeper understanding of the multiple ways in which law can be used to improve health, the O'Neill Institute hopes to advance scholarship, research, and teaching that will encourage key decisionmakers in the public, private, and civil society sectors to employ the law as a positive tool for enabling more people in the United States and throughout the world to lead healthier lives.

- Teaching. Georgetown is educating future generations of students who will become - upon their graduation - policymakers, health professionals, business leaders, scholars, attorneys, physicians, nurses, scientists, diplomats, judges, chief executive officers, and leaders in many other private, public, and nonprofit fields of endeavor. The O'Neill Institute helps to prepare graduates to engage in multidisciplinary conversations about national and global health care law and policy and to rigorously analyze the theoretical, philosophical, political, cultural, economic, scientific, and ethical bases for understanding and addressing health problems.

- Scholarship. O'Neill supports world-class research that is applied to urgent health problems, using a complex, comprehensive, interdisciplinary, and transnational approach to go beyond a narrow vision of health law that focuses solely on health care as an industry or as a scientific endeavor.

- Reflective Problem-Solving. For select high-priority issues, the O'Neill Institute organizes reflective problem-solving initiatives in which the Institute seeks to bridge the gap between key policymakers in the public, private, and civil society sectors and the intellectual talent and knowledge that resides in academia.

O’NEILl INSTITUTE FOR NATIONAL AND GLOBAL HEALTH LAW 


\section{OVERVIEW \\ LEGAL SOLUTIONS IN HEALTH REFORM}

The American public has increasingly identified health care as a key issue of concern. In order to address the multiple problems relating to the access and affordability of health care, President Obama and federal lawmakers across the political spectrum continue to call for major health reform. In any debate on health reform, a predictable set of complex policy, management, economic, and legal issues is likely to be raised. Due to the diverse interests involved, these issues could lead to a series of high-stakes policy debates. Therefore, it is critical that advocates of reform strategies anticipate such issues in order to decrease the likelihood that legally resolvable questions become barriers to substantive health reform. In an effort to frame and study legal challenges and solutions in advance of the heat of political debate, the O’Neill Institute for National and Global Health Law at Georgetown University and the Robert Wood Johnson Foundation have crafted the "Legal Solutions in Health Reform” project.

This project aims to identify practical, workable solutions to the kinds of legal issues that may arise in any upcoming federal health reform debate. While other academic and research organizations are exploring important policy, management, and economic questions relating to health reform, the O'Neill Institute has focused solely on the critical legal issues relating to federal health reform. The target audience includes elected officials and their staff, attorneys who work in key executive and legislative branch agencies, private industry lawyers, academic institutions, and other key players. This project attempts to pave the road towards improved health care for the nation by providing stakeholders a concise analysis of the complex legal issues relating to health reform, and a clear articulation of the range of solutions available.

\section{Legal Issues V. Policy Issues}

Among the major issues in federal health reform, there are recurring questions that are policybased and those that are legally-based. Many times questions of policy and of law overlap and cannot be considered in isolation. However, for the purpose of this project, we draw the distinction between law and policy based on the presence of clear legal permission or prohibition.

Under this distinction, policy issues include larger-scale questions such as what basic model of health reform to use, as well as more technical questions such as what threshold to use for poverty level subsidies and cost-sharing for preventive services. In contrast, legal issues are those involving constitutional, statutory, or regulatory questions such as whether the Constitution allows a certain congressional action or whether particular laws run parallel or conflict.

Based on this dividing line of clear permission or prohibition, policy questions can be framed as those beginning with, "Should we...?", and legal questions can be framed as those beginning with, "Can we...?" The focus of this paper will be the latter, broken into three particular categories: 1) "Under the Constitution, can we ever...?”; 2) "Under current statutes and regulations, can we now...?”; 3) “ Under the current regulatory scheme, how do we...?” This final set of questions tends to be mixed questions of policy, law, and good legislative drafting.

O’NEILl INSTITUTE FOR NATIONAL AND GLOBAL HEALTH LAW 


\section{Purpose and Layout of the Project}

This project is an effort to frame and study legal challenges and solutions in advance of the heat of political debate. This effort is undertaken with the optimistic view that all legal problems addressed are either soluble or avoidable. Rather than setting up roadblocks, this project is a constructive activity, attempting to pave the road towards improved health care for the nation. Consequently, it does not attempt to create consensus solutions for the identified problems nor is it an attempt to provide a unified field theory of how to provide health insurance in America. Furthermore, this project does not attempt to choose among the currently competing proposals or make recommendations among them. Instead, it is a comprehensive project written to provide policy makers, attorneys, and other key stakeholders with a concise analysis of the complex legal issues relating to health reform and a clear articulation of the range of solutions available for resolving those questions.

\section{LEGAL ISSUES}

Based on surveys of current health policy meetings and agendas, popular and professional press, and current health reform proposals, our team formulated a list of legal issues relating to federal health reform. After much research, discussion, and expert advice and review, our initial list of over 50 legal issues was narrowed to ten. An initial framing paper was drafted which identified these ten legal issues and briefly outlined the main components of each. In May of 2008, a bipartisan consultation session was convened to provide concrete feedback on the choice and framing of the legal issues. The attendees of the consultation session included congressional staff, executive branch officials, advocates, attorneys, employers, and representatives of a wide range of interests affected by health reform. Feedback and analysis from this session further narrowed the ten issues to eight key legal issues which warranted in depth analysis of the current law.

These eight pertinent issues are truly legal in nature and must be addressed in any significant reform proposal to avoid needless debate or pitfalls as policy decisions are made. There are multiple other legal issues that will arise as the discussion evolves and, if a federal policy is adopted, the system changes. In this project, however, we have targeted the issues essential for an immediate discussion of federal health reform.

O’NEILl INSTITUTE FOR NATIONAL AND GLOBAL HEALTH LAW 


\section{O’Neill Institute}

for National and Global Health Law

\section{LEgAL Solutions IN HEALTh REFoRM PROJECT}

JOHN T. MONAHAN, JD

Research Professor

Georgetown Health Policy Institute

Co-Director

Legal Solutions in Health Reform

JACQUELINE R. SCOTT, JD, ML

Adjunct Professor, Senior Fellow

Harrison Institute for Public Law

Georgetown Law

BENJAMIN E. BERKMAN, JD, MPH

Former Deputy Director \& Adjunct Professor

O’Neill Institute

Georgetown Law

\section{SHEILA P. BURKe, MPA, RN}

Research Professor

Georgetown Public Policy Institute

Distinguished Visitor, O’Neill Institute

Adjunct Lecturer and Senior Faculty Research

Fellow, Harvard University

John F. Kennedy School of Government

LisBeTH A. ZEgGANE

Former RWJF Project Assistant

O'Neill Institute
TIMOTHY M. WESTMORELAND, JD

Visiting Professor of Law

Georgetown Law

Co-Director

Legal Solutions in Health Reform

SARA P. HoverTer, JD, LLM

Staff Attorney, Adjunct Professor

Harrison Institute for Public Law

Georgetown Law

JACK EBELER, MPA

Distinguished Visitor, O’Neill Institute

Ebeler Consulting

SANDY H. HAN, JD, LLM

Teaching Fellow

Harrison Institute for Public Law

Georgetown Law

ELENORA E. CONNORS, JD, MPH

Fellow

O’Neill Institute

Georgetown Law

Mariesa M. Martin

RWJF Project Assistant

O'Neill Institute

Special thanks to the following individuals who contributed to the editing and production of the Legal Solutions in Health Reform Series, as well as the drafting of the Executive Summaries: Brian Bowen, Astrid Dorélien, Marissa Hornsby, Amy Killelea, Melanie MacLean, Anya Prince, and Luis Rodriguez. Also special thanks to John Kraemer for editing and production assistance. 


\section{LEGAL SOLUTIONS IN HEALTH REFORM \\ LEAD AUTHORS}

Executive Authority

Madhu Chugh, JD, MPP

Law Clerk

U.S. Court of Appeals for the D.C. Circuit

Washington, D.C.

Tax Credits for Health

Fred T. Goldberg, Jr., Esq.

Partner

Skadden, Arps, Slate, Meagher \& Flom, LLP

Washington, D.C.

\section{Insurance Exchanges}

Timothy S. Jost, JD

Robert L. Willet Family Professorship of Law

Washington \& Lee School of Law

Lexington, V.A.

Privacy and Security of Information

Deven McGraw, JD, LLM, MPH

Director, Health Privacy Project

Center for Democracy \& Technology

Washington, D.C.
Individual Mandates

Mark A. Hall, JD

Fred D. \& Elizabeth Turnpage

Professor of Law

Wake Forest University School of Law

Winston-Salem, N.C.

\section{ERISA}

Peter D. Jacobson, JD, MPH

Professor of Health Law \& Policy

Director, Center for Law, Ethics, and Health University of Michigan

School of Public Health

Ann Arbor, M.I.

Purchase of Insurance Across State Lines Stephanie Kanwit, JD

Special Counsel \& Healthcare Consultant America's Health Insurance Plans

Washington, D.C.

Insurance Discrimination Based on Health Status

Sara Rosenbaum, JD

Harold and Jane Hirsh Professor of Health

Law \& Policy

Chair, Department of Health Policy

The George Washington University School

of Public Health and Health Services

Washington, D.C. 


\section{About The Author}

Madhu Chugh, J.D., M.P.P., is currently clerking for Judge Thomas B. Griffith on the U.S. Court of Appeals for the District of Columbia Circuit. During the 2004 presidential election, Madhu served as Director of Health Care Policy for the Kerry-Edwards campaign. She was the Policy Director on former Governor Jeanne Shaheen's 2002 Senate campaign, and from 2001-2002, she worked on health care policy for Senator Edward Kennedy. In 1998, Madhu served as deputy communications director on Tom Vilsack's successful gubernatorial campaign in Iowa, where he was the first Democrat elected governor in more than 30 years. While maintaining her communications duties in Governor Vilsack's office, Madhu helped pass legislation that invested Iowa's share of a large tobacco settlement in creating and expanding health care programs. Madhu graduated from Yale Law School where she was a Book Reviews \& Features Editor on The Yale Law Journal. She also has a master's degree in public policy from the Kennedy School at Harvard University, during which time she received the Soros Fellowship for New Americans. She majored in journalism and government at the University of Texas at Austin, graduating with honors and election to Phi Beta Kappa. During her senior year, Madhu received the university's most prestigious award, the University of Texas Outstanding Female Student of the Year.

O’Neill Institute for National and Global Health LaW

Georgetown LaW | 600 NEW Jersey AVENUE NW | WASHINGTON, DC 20001

www.oneillinstitute.org 


\section{EXECUTIVE SUMMARY \\ Prepared by the O'Neill Institute}

INTRODUCTION:

Within constitutional and statutory boundaries, the Obama Administration can use its executive authority and administrative tools to reform health care incrementally without Congressional approval. Under current law, the Administration can:

1) promote its policy goals through demonstration projects;

2) increase the use of health information technology;

3) reduce drug costs;

4) increase coverage portability; and

5) expand SCHIP eligibility.

The Administration does not, however, have the unilateral power to establish a national health insurance exchange, create a new small business health tax credit, or require employers to "payor-play.”

TOOLS OF THE PRESIDENTIAL ADMINISTRATION TO REFORM HEALTH CARE: The Obama Administration has three primary tools to direct the actions of administrative agencies: regulations, sub-regulatory guidance, and executive orders. Administrative agencies promulgate regulations pursuant to Congressional delegations of authority in statutes. Subregulatory guidance implements policy within an executive agency and includes letters, memoranda, determinations, agreements, findings, and other types of directives. Presidents employ executive orders to direct the actions of agency employees and instruct them to create or implement particular policies.

\section{PROMOTE POLICY GOALS THROUGH DEMONSTRATION PROJECTS:}

The Administration can pursue its policy goals through Medicaid, Medicare, and SCHIP demonstration projects. Section 1115 of the Social Security Act (Act) gives the Secretary of Health and Human Services (HHS) broad authority to waive certain Medicaid and SCHIP requirements for states to test new ideas. Similarly, Section 222 of the Social Security Amendments of 1972 gives the Secretary authority to develop demonstration projects to test provider quality initiatives. For example, the Secretary could allow states to expand coverage for low-income adults using Section 1115 waivers, or implement "pay-for-performance" for care received under Medicare using Section 222 waivers.

\section{INCREASE THE USE OF HEALTH INFORMATION TECHNOLOGY:}

The new Administration can increase the use of health information technology (IT) through several ways. President Obama can issue an executive order similar to Executive Order 13410, which directed administrative agencies to complete a comprehensive review of the numerous health IT programs currently underway and to coordinate the activities of various agencies. Additionally, the Centers for Medicare \& Medicaid Services (CMS) can promulgate regulations to expand the scope of the physician reimbursement program. Finally, CMS can create more demonstration projects similar to the Electronic Health Records Demonstration, which reimburses physicians who adopt health IT and report performance data.

O’NEILl INSTITUTE FOR NATIONAL AND GLOBAL HEALTH LAW 


\section{REDUCE DRUG COSTS IN MEDICARE:}

The Administration can reduce drug costs by creating a Medicare drug re-importation program under section 1121 of the Medicare Modernization Act of 2003 (MMA). In addition, the Secretary can lower costs by negotiating payments with Medicare Administrator Contractors under its section 911 contracting authority. Because the MMA explicitly denies the Administration the authority to negotiate Medicare Part D drug prices with manufacturers for drugs, legislative amendments would be necessary to give the Secretary negotiating power.

\section{ENHANCE PATIENT PROTECTIONS AND IMPROVE COVERAGE PORTABILITY:}

There are two ways that the Administration can enhance patient protections and improve coverage portability with fewer restrictions. First, the Administration can institute greater patient protections in the Federal Employees Health Benefits Plan (FEHBP) to help policymakers better understand these protections before enacting them for the insurance industry. Second, the Administration can amend the Final Rule for the Health Insurance Portability and Accountability Act (HIPAA) to improve coverage portability for individuals.

\section{LIFT AGENCY DIRECTIVES THAT RESTRICT SCHIP AND MEDICAID:}

The Administration can expand SCHIP and Medicaid eligibility by reconsidering current regulations that restrict eligibility and cut funding. For example, President Obama issued a Memorandum on February 4, 2009, requesting that the Secretary of the Department of Health and Human Services immediately withdraw an August 17, 2007, letter -- which limits state health officials' discretion to set income eligibility caps for families whose children participate in the children's health insurance program -- and implement SCHIP without the requirements it imposed.

\section{BUILD ON FEHBP:}

Numerous policymakers have proposed opening the Federal Employees Health Benefit Plan (FEHBP) to the public or creating a similar program for Americans with pre-existing conditions. The new Administration could memorialize many of FEHBP's best practices through executive orders or memoranda so that private insurers and the federal government can better understand what policies work to reduce costs and ensure quality care. Making coverage available to members of the public through the program, however, would require Congressional action.

\section{POLICIES THAT REQUIRE LEGISLATIVE ENACTMENT:}

Although the Administration has significant opportunities to invoke its executive authority, it can only act within the bounds of a statute. There are numerous policy changes that would require legislative enactment first. Any changes to the tax code or proposals to purchase insurance across state lines, for example, would require legislative action.

\section{CONCLUSION:}

Although the President's executive authority could allow him to begin implementing crucial reforms, he also must pay careful attention to legal, budgetary, and legislative constraints on that authority. The above policy recommendations are examples of ways that the new Administration can take incremental steps toward health care reform. There are many opportunities for using the President's executive authority and administrative tools to lay the foundation for more expansive health reform.

O’NEILl INSTITUTE FOR NATIONAL AND GLOBAL HEALTH LAW 


\section{Legal Solutions in Health Reform: \\ Executive Authority to Reform Health: Options and Limitations Madhu Chugh*}

\section{Introduction}

Presidential power has provoked increasingly vigorous debate since the turn of this century. In recent years, scholars and lawyers have been grappling with how Congress's dictates may limit the President's Commander-in-Chief power to detain enemy combatants at Guantanamo Bay, to fight wars abroad, and to conduct intelligence activities at home. But policymakers have not yet explored the many possibilities for invoking the President's "Take Care" power to change health care policy.

This paper explores the scope and limits of President Barack Obama's ability to invoke his executive authority to reform health care. Specifically, it identifies ways the Obama Administration can use directives to: (1) expand Medicaid and SCHIP coverage through section 1115 waivers; (2) test quality initiatives through Medicare demonstration authority; (3) expand health information technology; (4) allow drug reimportation and experiment with contracting power under Medicare; (5) enhance patient protections and private coverage requirements; (6) lift coverage restrictions on Medicaid and SCHIP; and (7) build on the health insurance program for federal employees. Consistent with the mission of the Legal Solutions in Health Reform project, this paper does not endorse a particular policy. Instead of recommending "what," it explains "how."

Policymakers in the Obama Administration are not the only ones who need to understand the scope of executive authority. As Congress begins to tackle its health care agenda, policymakers on the Hill should know how proposed legislation would affect the President's power. More specific statutes would limit the executive branch's ability to make policy decisions. On the other hand, health reform legislation that provides only the skeleton of a new program would provide greater opportunities for President Obama and his agencies to fill out the details. There is ample precedent for this approach. For example, Congress opened the door for President Roosevelt's groundbreaking New Deal policies by authorizing the creation of new programs while providing minimal guidance on key details of administrative implementation. ${ }^{1}$ In addition, legislators should keep in mind that how they draft legislation can affect the level of deference that courts provide to agency interpretations of statutes. Fewer statutory details mean greater judicial deference to the executive in the event of a challenge.

Part I provides a user's manual on executive authority. With an eye toward the non-legal audience, it describes the various administrative tools at the President's disposal. Part II moves the discussion from the conceptual to the specific. It suggests ways that President Obama could use administrative tools to reform health care. While this paper focuses on the "how," it borrows the "what" from many existing health care proposals, including policies offered during the 2008 Presidential campaign by Barack Obama and John McCain. Part II ends by identifying a few areas in which the President could not use administrative tools to make policy changes.

O’NEILl INSTITUTE FOR NATIONAL AND GLOBAL HEALTH LAW

GEORGETOWN LAW | 600 NEW JERSEY AVENUE NW | WASHINGTON, DC 20001

www.oneillinstitute.org 
Part III assesses the potential legal, budgetary, and legislative constraints on a President's Article II powers to interpret the law. It explains how Congress and the courts can limit the President's latitude to make policy changes through the administrative process. More broadly, it highlights the continuing struggle between the three branches to influence health policy. The paper concludes with a discussion of why congressional lawmakers should consider how their proposed legislation would impact executive authority as they craft health reform proposals.

\section{Overview of Executive Authority}

Decreasing health care costs, expanding coverage, modernizing the delivery of care-there are an endless number of policy proposals for reforming our health care system. Policymakers in Congress and in the Obama Administration are crafting the key reform proposals that will shape their agenda. It is important to remember that the process through which these policies are created can be just as critical to the overall success as getting the substance of the policy right. Presidents have a wide array of administrative options at their disposal. This section briefly describes these various tools and explains how executive authority has evolved during the past thirty years.

Administrative law scholars deem the various tools at a President's disposal as "presidential directives." There are numerous types of directives, but all share the general purpose of "establishing new policy, decreeing the commencement or cessation of some action, or ordaining that notice be given to some declaration."2 Directives can be divided into three categories: executive orders and proclamations, regulatory actions, and sub-regulatory guidance. In addition, Presidents use signing statements to communicate their disagreement with statutory provisions they believe encroach on their executive authority. As explained in Part III, courts scrutinize each type of administrative tool to varying degrees when reviewing the legality of administrative action.

\section{A. Executive Orders and Proclamations}

Perhaps the most well-known directive is the executive order, which dates back to George Washington's Administration. Presidents employ executive orders to direct the actions of agency employees and instruct subordinates to create or implement particular policies. ${ }^{3}$ The sources of authority for executive orders are twofold: one is constitutional, including the Article II requirement that the President "take Care that the Laws be faithfully executed," 4 and the other is any statutory language that delegates specific power to the executive branch to implement and flesh out the details of a duly enacted program. Executive orders can make significant policy changes, particularly during wartime or when a President relies on his constitutional powers to deal with an emergency situation. ${ }^{5}$ For example, President Abraham Lincoln's Emancipation Proclamation consisted of two executive orders freeing slaves in most of the confederate states. ${ }^{6}$

Proclamations, another type of presidential directive, differ from executive orders in that they are generally aimed at the public rather than agencies. Modern-day proclamations generally encourage activity or recognize interests rather than direct specific action. ${ }^{7}$ Otherwise, most of the differences between proclamations and executive orders are formal rather than substantive. ${ }^{8}$

O’NEILL INSTITUTE FOR NATIONAL AND GLOBAL HEALTH LAW

GEORGETOWN LAW | 600 NEW JERSEY AVENUE NW | WASHINGTON, DC 20001 www.oneillinstitute.org 
Like executive orders, Presidents must publish all proclamations pursuant to the requirements of the Federal Register Act of $1935 .^{9}$

\section{B. Regulatory Actions}

Regulations - also known as rules—are a common administrative tool invoked by agencies. The Administrative Procedure Act ("APA") defines them as "the whole or part of an agency statement of general or particular applicability and future effect designed to implement, interpret, or prescribe law or policy." 10 Often, Congress will delegate authority to agencies to flesh out the details of a new program by promulgating regulations. These rules not only must stay within the bounds of the statutory language, they also must be consistent with the Constitution (like any other directive). In addition, the APA requires agencies to notify the public before issuing a rule so that interested parties can comment on the proposal. ${ }^{11}$ There is a large body of literature analyzing the various permutations of the regulatory process, as well as the legal weight afforded to regulations. This Paper touches on these issues in Part III.

\section{Sub-regulatory Guidance}

Sub-regulatory guidance includes letters, memoranda, determinations, agreements, findings, and other types of directives. ${ }^{12}$ Agencies often use sub-regulatory guidance to implement demonstration projects authorized by Congress, as explained in Part II. There is an open debate about whether this includes forms of communication typically associated with public relationsfor example, press releases and web pages. Presidents and their agencies have employed subregulatory guidance to direct and govern the activities of federal employees, and, much like executive orders and proclamations, they may have the force of law if published in the Federal Register and issued pursuant to a valid source of executive authority. ${ }^{13}$ The only difference between sub-regulatory guidance and executive orders and proclamations is that there are no mandatory publication requirements for sub-regulatory guidance unless 1) Congress has required it or 2) the directives have "general applicability and legal effect."14

\section{Signing Statements}

Although not a presidential directive (partly because it does not establish policy), a signing statement is another tool in the executive's arsenal. When presidents sign bills into law, they sometimes issue official pronouncements "to forward the President's interpretation of the statutory language; to assert constitutional objections to the provisions contained therein; and ... to announce that the provisions of the law will be administered in a manner that comports with the Administration's conception of the President's constitutional prerogatives."15 Often, Presidents use signing statements to communicate disagreement about statutory provisions that they believe encroach on their executive authority. Even though Presidents technically began using signing statements more than two hundred years ago, President Ronald Reagan was the first to invoke them in voicing substantial constitutional concerns regarding statutory language. ${ }^{16}$ It is unclear whether signing statements have the force of law. Many scholars argue that if a President's application of the statute conflicts with the wishes of Congress, signing statements do not provide an authoritative source of power to rectify or even assuage an unlawful interpretation. ${ }^{17}$ No court of law, however, has answered this question.

O’NEILl INSTITUTE FOR NATIONAL AND GLOBAL HEALTH LAW

GEORGETOWN LAW | 600 NEW JERSEY AVENUE NW | WASHINGTON, DC 20001 www.oneillinstitute.org 


\section{$\underline{\text { II. Legal Prescriptions for Policy Proposals }}$}

The economic crisis and growing federal deficit may limit the prospect of congressional action on big-ticket items. Or, conversely, the dire economic situation might create an environment in which “deficits don't matter," thereby enabling the President and Congress to propose significant health reform legislation. No matter which congressional strategy the Obama Administration embraces, there are numerous ways the President can rely on his executive authority to create policies that help reshape federal programs and make improvements to the health care system. In addition, President Obama can invoke various administrative tools to lay the groundwork for future reform, much like Presidents Roosevelt, Truman, Kennedy, and Johnson did in the area of civil rights. ${ }^{18}$

This section suggests ways that President Obama could use executive power to make health care policy without relying on Congress. The proposals below reflect some areas of common ground between the health care proposals offered by President Barack Obama and Senator John McCain during the presidential campaign, as well as the numerous legislative proposals currently being considered. This paper neither endorses nor condemns any of the policies; rather, it simply explains how the directives explained above may help the next President achieve some of his goals. The section ends by identifying policy proposals that would require enactment of legislation.

\section{A. Expand Medicaid \& SCHIP Coverage Through Section 1115 Waiver Authority}

Nearly all of the current health reform proposals include some expansion of Medicaid and SCHIP. President Obama has discussed changing eligibility requirements, while Senator McCain suggested experimenting with Medicaid's payment scheme to allow greater coordinated care and alternative forms of access. Senators Ron Wyden and Robert Bennett have proposed converting Medicaid and SCHIP into supplemental insurance programs that would "wrap around" private coverage. ${ }^{19}$ Senators Edward Kennedy and Max Baucus both have voiced strong support for instituting a variety of mechanisms to increase the number of children and adults covered.

One of the most significant sources of executive authority for testing these ideas on a large scale is section 1115 of the Social Security Act. ${ }^{20}$ Congress enacted this provision to allow states to obtain waivers from the federal government to create demonstration projects that were limited in scope and short-term in nature. But the evolution of section 1115 illustrates how President Obama could use the waiver authority to allow significant flexibility in state Medicaid programs, including coverage expansions.

Section 1115 provides broad and general authority to the Secretary of the Department of Health and Human Services (HHS) to waive statutory and regulatory provisions without congressional approval or public notice. The executive branch has never issued regulations defining the standards or procedures that states must follow to win approval of proposed changes to the state programs. $^{21}$ Instead, HHS has used a variety of informal, non-binding methods to communicate procedures and rules for the program. HHS has, for example, published notices in the Federal Register; issued operations manuals; and disseminated department letters approving state programs, as well as letters to various state officials, researchers, and policymakers. ${ }^{22}$

O’NEILl INSTITUTE FOR NATIONAL AND GLOBAL HEALTH LAW

GEORGETOWN LAW | 600 NEW JERSEY AVENUE NW | WASHINGTON, DC 20001 www.oneillinstitute.org 
For example, in September 1994, HHS published a public notice in the Federal Register announcing that the Clinton Administration would interpret section 1115 waiver authority broadly. $^{23}$ One of the most significant aspects of the public notice was its endorsement of demonstration programs that lasted longer than five years. This meant that the duration of an experimental project was no longer an important factor in determining whether it would win federal approval. ${ }^{24}$ In addition, the costs of a demonstration project would be evaluated across the project's lifespan rather than on an annual basis. ${ }^{25}$ Finally, the Administration allowed states to redirect monies from other parts of their Medicaid programs to demonstration projects.

After the Clinton Administration opened the door to massive changes in Medicaid through the section 1115 waiver program, the Bush Administration embarked on an era of significantly greater state flexibility. In August 2001, HHS Secretary Tommy Thompson announced the creation of the Health Insurance Flexibility and Accountability ("HIFA") initiative. ${ }^{26}$ These waivers provide an expedited review process for states requesting waiver authority to loosen Medicaid requirements. In addition, HIFA's provisions help make waivers more widely available. $^{27}$

What started out as a fairly non-existent research and demonstration program in the 1960s has burgeoned into a shadow federal entitlement program. The Congressional Research Service (CRS) reports that as of January 2007, there have been 110 operational Medicaid and SCHIP waivers granted under section $1115 .^{28}$ In FY2005, federal spending on these waivers totaled \$26.6 billion, accounting for nearly $15 \%$ of all federal Medicaid spending. ${ }^{29}$ Even more surprising, nearly 14 million Americans receive Medicaid coverage through a section 1115 waiver program.

States are taking enormous advantage of the waiver process. The Obama Administration must decide whether it wishes to continue this approach. Some waiver programs have existed for more than fifteen years: states appear to re-apply and receive approval for the same program when nearing the expiration date. Numerous states have also created section 1115 waiver programs that apply statewide: many states provide comprehensive benefits through these programs instead of using them solely to test financing schemes or benefit packages. Several states have also used waivers to create "me, too" programs that are carbon copies of programs in other states. For example, a number of states have embraced the waiver program for providing family planning coverage.

In addition, the Obama Administration could allow states to continue using waivers to forgo some of the traditional requirements in Medicaid. States must ordinarily provide coverage to all those in a particular group who are eligible. ${ }^{30}$ Medicaid unequivocally forbids enrollment caps, even when state budgets may not be able to cover everyone who is eligible. Despite this requirement, previous administrations have approved state waiver programs that cap the number of beneficiaries covered. Some states have also used waivers to create significant variation in the program design or benefits packages across the state, even though under the traditional Medicaid program these packages must be uniform for all participants. Many states are also providing different benefits packages to different groups of beneficiaries under the waiver programs, disregarding Medicaid's mandate that all persons eligible for health care coverage must receive a uniform benefits package. ${ }^{31}$

O’NEILl INSTITUTE FOR NATIONAL AND GLOBAL HEALTH LAW GEORGETOWN LAW | 600 NEW JERSEY AVENUE NW | WASHINGTON, DC 20001 www.oneillinstitute.org 
The evolution of section 1115 reveals the significant executive authority available to President Obama to make changes to Medicaid and SCHIP. There are numerous opportunities for the new Administration and Congress to experiment with many of the policy ideas that have been proposed recently, including expanding eligibility, changing benefits packages, trying new payment schemes, and encouraging coordinated care among physicians serving Medicaid beneficiaries.

\section{B. Test Quality Initiatives Through Medicare Demonstration Authority}

President Obama, John McCain, and a number of legislators have recommended changes to the Medicare program. Senator McCain, for example, suggested that Medicare modify its payment scheme to base provider compensation on diagnosis, prevention, and care coordination. He also proposed eliminating reimbursements for preventable medical errors and requiring disclosure of medical outcomes, quality of care, and costs. President Obama has discussed plans to base physician payment on performance, as well as to require the use of disease management programs to help those suffering from chronic conditions.

Medicare provides a significant source of executive authority for the President to determine whether these policies are worth pursuing on a larger scale. Little known and not often used, demonstration authority under the Medicare program would allow the Obama Administration to test new policies on a temporary basis. Section 222(a) of the Social Security Amendments of 1972 is the source of the executive's waiver authority. ${ }^{32}$ The Centers for Medicare and Medicaid Services (CMS) may invoke this authority to "develop and engage in experiments and demonstration projects" to accomplish a variety of goals, including experimenting with new payment or reimbursement methods to increase program efficiency; testing policies that reduce Medicare spending; and trying new contracting methods with providers. ${ }^{33}$ In so doing, the agency has extensive authority to forgo existing payment requirements for participants in the demonstration projects, thereby raising the possibility of increased Medicare spending. ${ }^{34}$ In addition, the Secretary may waive compliance with other Medicare requirements as long as they relate to payment or reimbursement. ${ }^{35}$

Despite this significant grant of demonstration authority, previous administrations have not invoked it often. Part of the reason may be that Congress usually authorizes the creation of Medicare demonstration projects, as it did with the Medicare Modernization Act of 2003, thereby limiting the need to rely solely on section 222 waivers. ${ }^{36}$ Also, CMS has tended to invoke its section 222 authority most often to create capitated payment schemes in "Medicare/Medicaid integration projects for dual eligibles:" elderly and impoverished beneficiaries who receive benefits from both entitlement programs. ${ }^{37}$

There are currently about fifty existing demonstration projects that have been authorized by section 222 waivers. ${ }^{38}$ A review of these projects reveals that CMS is testing payment schemes to accomplish a variety of goals, including paying doctors for their success (i.e., performance) in satisfying clinical measures; ${ }^{39}$ providing hospice services for beneficiaries living in rural areas; ${ }^{40}$ expanding disease management and coordinated care; ${ }^{41}$ and creating new programs that improve the quality of care delivered, as mandated by section 646 of the 2003 Medicare drug bill. ${ }^{42}$ Therefore, the Obama Administration could expand the use of its section 222 authority to test

O’NEILL INSTITUTE FOR NATIONAL AND GLOBAL HEALTH LAW

GEORGETOWN LAW | 600 NEW JERSEY AVENUE NW | WASHINGTON, DC 20001 www.oneillinstitute.org 
many, if not all, of the Medicare policies that the President proposed during the campaign. In addition, Congress could pass legislation to encourage experimentation of quality and other programs pursuant to the President's section 222 power.

\section{Expand Health Information Technology}

Expanding the use of health information technology is a popular bipartisan policy that finds its way into most legislative reform proposals. The potential benefits are three-fold: using health IT could make the health care system more efficient, improve the quality of care delivered, and reduce costs in the long-run. ${ }^{43}$ Policymakers must resolve numerous issues in designing and implementing health IT programs, including financing new computer systems, protecting patient privacy, and creating common computer "languages" and standardizing codes so numerous actors - doctors, hospitals, insurers, etc. - can exchange information effectively and efficiently. ${ }^{44}$

This paper sets aside those difficult policy questions and addresses how the Obama Administration could use existing sources of authority to expand upon the existing policies. With numerous health IT programs already underway in the executive branch comes the likelihood for confusion and duplication of efforts. For example, at least eight agencies or organizations within HHS are currently involved in health IT efforts - including the American Health Information Community, the Office of the National Coordinator for Health Information Technology, the Federal Health Architecture, the Agency for Healthcare Research and Quality (which provides approximately $\$ 170$ million in technology grants and contracts), the Health Resources and Services Administration, Indian Health Services, the National Institutes of Health, and the Centers for Medicaid and Medicare Services. This does not include separate electronic health record systems operated by the Department of Defense and the Veterans Health Administration, or the many private sector initiatives being led by insurers and other non-profit groups.

Even though the National Coordinator is partly responsible for coordinating executive branch efforts, his primary responsibility is to develop a national infrastructure so a majority of Americans have an electronic medical record by $2014 .{ }^{45}$ Obtaining a comprehensive assessment of all the various efforts, therefore, is necessary to know where authority lies and how Congress can most effectively expand the President's power to significantly ramp up health IT efforts. The new administration could issue executive orders not only to direct agencies to complete a comprehensive review by a certain date, but also to help coordinate the activities of various agencies. $^{46}$

Additionally, as part of the Medicare physician payment legislation passed in July 2008, doctors may receive reimbursement increases for participating in an electronic prescribing program in Medicare Part D. ${ }^{47}$ Even though the legislation sets the percentage increase in reimbursements, CMS has significant authority to fill out the details of the program within the confines of the statute. For example, CMS may determine the numerous rules that physicians must follow for how and what kind of data (i.e., drug type, benefits, potential chemical interactions, availability of alternatives) they should report -- rules that will significantly impact the number of participants and overall success of the program. ${ }^{48}$

O’NEILl INSTITUTE FOR NATIONAL AND GLOBAL HEALTH LAW 
Although the Bush Administration has made progress in setting some of these standards pursuant to authority provided in the Medicare Modernization Act (MMA), ${ }^{49}$ which created Medicare Part D, much more work is needed for implementing the new reimbursement program. $^{50}$ The Administrator also may provide hardship exceptions for providers who have difficulty satisfying the rules, including those in rural areas "without sufficient Internet access." 51 The new program, which was scheduled to begin on January 1, 2009, offers great opportunities for the new administration to experiment with e-prescribing policies until the fiveyear sunset in 2013. ${ }^{52}$ Therefore, the physician reimbursement program is a source of significant authority to quickly expand the use of e-prescribing.

Finally, the new administration could rely on CMS's extensive demonstration authority in the Medicare program, as previously discussed, to experiment with reimbursement schemes that base payment on the quality of care provided (i.e., performance) and the use of technology. A recent demonstration project created by the Bush Administration provides a useful example. The Electronic Health Records Demonstration attempts to expand the use of electronic health records to help reduce both medical errors and costs. ${ }^{53}$ CMS does not provide any up-front grants or payments to help physicians install the necessary programs. ${ }^{54}$ Instead, the program pays primary care physicians who adopt electronic health records and then use them to provide data (which indicates performance) on a number of clinical quality measures, including for chronic conditions such as diabetes and heart disease. ${ }^{55}$

There are three types of payments: an annual incentive payment lasting the duration of the fiveyear program; a payment after the second year for reporting the data; and a payment after each of the remaining years for performance. ${ }^{56}$ The program uses existing measures endorsed by the National Quality Forum and used by health plans for years. ${ }^{57}$ Such a program reflects the breadth of opportunities available to President Obama to test various policies before seeking congressional approval for health IT programs.

\section{Promulgate Rules to Allow Drug Re-importation, As Well As Experiment With the Secretary's Contracting Power Under Medicare}

Two important sources of executive authority provide potential opportunities for the new administration to reduce federal drug spending. In 2003, Congress passed the MMA, ${ }^{58}$ making the biggest statutory change to the Medicare program since its enactment in 1965. The MMA explicitly denies the Secretary the power to negotiate drug prices with manufacturers under Part $\mathrm{D}^{59}$; therefore, the Obama administration will not be able to negotiate drug prices unless Congress amends section 1860D-11(i) of the MMA. However, the bill significantly expands the regulatory power of the HHS Secretary to implement the new drug benefit. Yet the Secretary has not taken full advantage of the congressional delegations of authority. Section 1121, in particular, gives the Secretary the power to allow U.S. licensed pharmacists and prescription drug wholesalers to re-import U.S. manufactured medications from Canada. ${ }^{60}$ The statute explicitly provides rulemaking authority to the Secretary to supply the details of the program without returning to Congress for additional grants of authority.

Before moving forward, however, HHS must satisfy some threshold safety measures, including certifying to Congress that the program "will pose no additional risk to the public's health and safety." ${ }^{11}$ In addition, importers must provide a host of information and promise to test re-

O’NEILl INSTITUTE FOR NATIONAL AND GLOBAL HEALTH LAW

GEORGETOWN LAW | 600 NEW JERSEY AVENUE NW | WASHINGTON, DC 20001 www.oneillinstitute.org 
imported drugs. Finally, the Department may provide waivers to individuals wishing to reimport drugs, although statistics reveal that millions of Americans already purchase drugs from other countries via the Internet. ${ }^{62}$ Because the Bush Administration did not invoke section 1121 to create a Medicare drug re-importation program, President Obama will have an opportunity to tap into this significant source of congressionally delegated power to help reduce Medicare drug spending.

Certainly, the recent news about contaminated products from China give some pause regarding the assurance of safety in a Medicare drug re-importation program. However, section 1121 only allows re-importation from Canada and provides broad authority to the Secretary to set specific safety guidelines before allowing foreign-made drugs to enter U.S. borders. This "safety assurance" power is crucial for any steps the President wishes to take to place formal guidelines on the drugs that individuals are bringing across U.S. borders.

Another source of potential executive power is section 911 of the MMA. ${ }^{63}$ Dubbed "Increased Flexibility in Medicare Administration," the statute grants the Department authority to enter into contracts with "providers of services, suppliers, and individuals" that administer the drug benefit. $^{64}$ Private insurers and other entities will serve as and largely replace the financial intermediaries that process the millions of claims they receive from providers each year.

The MMA's contracting language may provide the Obama Administration opportunities to invoke this authority to limit program costs. The legislative history notes that section 911 "would permit the Secretary to competitively contract with any eligible entity to serve as a Medicare Administrative Contractor (MAC)." 65 These new groups, operated by CMS, wield power to "mak[e] the payments" under Parts A and B of Medicare and to "determin[e] the amount of Medicare payments required to be made to providers and suppliers." ${ }^{66}$ The legislative history also conveys Congress's blessing to allow the Secretary to develop measurements for evaluating the MACs' performance. Given the broad power delegated to CMS to negotiate contracts and rely on competitive bidding, opportunities exist for the agency to help keep Medicare spending down through free-market tools. It is important to note, however, that this power is limited. The MMA constrains the executive's authority such that the Secretary may not use the authority to change drug prices or the delivery system under Part D. ${ }^{67}$ MACs must make payments pursuant to Title XVIII requirements. ${ }^{68}$

Given the recent media attention regarding the amounts Medicare pays Durable Medical Equipment (DME) manufacturers, there is significant concern about how the new administration will continue to implement this contracting authority. As CMS finishes choosing and negotiating with DME MACs and the contractors for Parts A and B, the terms that CMS sets in these contracts at the early stages of the program will have an enormous impact on the level of costs savings it can generate. ${ }^{69}$

\section{E. Enhance Patient Protections and Private Coverage Requirements}

Both President Obama and Senator McCain offered campaign proposals to regulate the activities of the insurance industry. These proposals can be divided into two groups generally: 1) protecting patients' rights and 2) ensuring affordable, portable coverage with fewer restrictions. In the area of patients' rights, President Obama could invoke his executive authority to shape the

O’NEILL INSTITUTE FOR NATIONAL AND GLOBAL HEALTH LAW

GEORGETOWN LAW | 600 NEW JERSEY AVENUE NW | WASHINGTON, DC 20001 www.oneillinstitute.org 
Federal Employees Health Benefits Plan (FEHBP) by ordering federal agencies to adopt consumer protections in their health insurance policies. ${ }^{70}$ President Clinton issued similar orders that directed the federal Office of Personnel Management (OPM) to punish insurers - possibly by terminating their contracts - when they did not comply with the requirements in his directives. ${ }^{71}$ This order fulfilled two goals: it expanded patients' rights for federal employees, and it laid the groundwork for future legislation on managed care by creating a precedent of rules applicable to a large, privately-insured group. ${ }^{72}$

The Senate made its most significant push for a Patients' Bill of Rights in 2001. Even though the bill ultimately was not enacted, Senator McCain joined with Senator Edward Kennedy to push legislation that demanded assurances of swift review and appeals processes for denial of coverage; added requirements on HMOs to remove barriers to specialty and emergency care; and provided enforcement mechanisms to ensure compliance by insurance companies. Despite its failure, opportunities remain for the Obama Administration to memorialize and apply many of these additional protections in the FEHBP through executive orders and memoranda. Given that approximately 8 million people participate in the program, creating these policies in the FEHBP would, at the very least, help policymakers understand what works before trying to enact these protections for the privately insured population at large.

The second source of executive authority originates with the Kennedy-Kassebaum legislation passed in 1996, also known as the Health Insurance Portability and Accountability Act (HIPAA). ${ }^{73}$ This legislation enacted new portability and continuity of coverage requirements and requires insurers to offer individuals with pre-existing conditions the same access to benefits as the general public. It does not, however, set price limits or guarantee affordability.

HIPAA explicitly gave the President rulemaking authority to implement various parts of the bill. $^{74}$ The Clinton Administration invoked this power to issue an interim rule detailing the portability requirements and other obligations imposed on insurers. This rule covered a host of important policy issues, from defining the terms of enrollment to placing limitations on preexisting condition exclusions to determining when employers are not liable for treating employees' ailments. ${ }^{75}$ The Departments of Treasury, Labor, and Health and Human Services continued to invite comments on the regulation until the end of the Clinton Administration, leaving it to the Bush Administration to finalize the guidelines pertaining to insurers. ${ }^{76}$

On December 30, 2004, the three departments issued the final rule. ${ }^{77}$ Comprising 81 pages in the Federal Register, HHS billed the changes as "regulations [that] essentially adopt the interim final rules issued by the three agencies in 1997, but include several significant modifications."78 A review of the current rule reveals that much of the contents of the interim rule remained; for example, it emphasizes the "narrowness of permissible pre-existing condition exclusions." ${ }^{79}$ Yet the current version made significant changes to the interim rule; for example, it allows insurers more latitude to impose a pre-existing condition exclusion for genetic illnesses. ${ }^{80}$ In addition, the new rule changed the requirements for HMO affiliation periods - the time before HMO coverage becomes effective when a plan is not required to provide benefits. HMOs can apply differing affiliation periods as long as they do not violate the nondiscrimination provisions in HIPAA. The language in the rule is broad enough, however, to allow insurers to potentially restrict coverage arbitrarily among various beneficiaries.

O’NEILl INSTITUTE FOR NATIONAL AND GLOBAL HEALTH LAW

GEORGETOWN LAW | 600 NEW JERSEY AVENUE NW | WASHINGTON, DC 20001 www.oneillinstitute.org 
During the campaign, President Obama said that he would prohibit insurers from denying coverage based on pre-existing conditions. ${ }^{81}$ The new administration may choose to reexamine the December 30, 2004, rule to determine whether it does enough to ensure continuous coverage and portability, and to limit the situations in which insurers may exclude coverage for those suffering from pre-existing conditions. Given the explicit rulemaking authority provided to the President in HIPAA, ${ }^{82}$ President Obama also has the opportunity to create greater protections through additional regulations and possibly new executive directives for private plans that provide coverage for federal employees. The source of authority and its bounds are clear. The big question facing the Obama Administration is whether it wants to invoke this fairly broad power to create more rules for how the insurance industry operates.

\section{F. Lift Agency Directives Restricting Coverage Under SCHIP and Medicaid}

The Bush Administration has issued a number of regulations that reduce Medicaid spending. These new policies, among other things, allow higher premiums and co-payments for medical care; ${ }^{83}$ eliminate funding for school-based outreach and enrollment programs; ${ }^{84}$ cut federal funding for graduate medical education programs at teaching hospitals; ${ }^{85}$ and limit the types of children's rehabilitative services (e.g., therapy for some developmental disabilities) that Medicaid will cover. ${ }^{86}$ Even though Congress has enacted moratoria on the vast majority of these rules, they provide only a temporary suspension. The cost-sharing rule alone could reduce state and federal spending by $\$ 2.5$ billion. ${ }^{87}$ The Congressional Budget Office estimates that the rest of the regulations could eliminate more than $\$ 21$ billion from the program, ${ }^{88}$ much of which may be absorbed by state and local governments. ${ }^{89}$

If the Obama Administration wishes to reconsider and possibly rescind these regulations, it could invoke its executive authority in a two-step process. First, President Obama could issue an executive order temporarily suspending or postponing action on regulations until further study of their impact. This would allow him time to determine whether previous rationales for the rules coincide with the his policy objectives - much like presidents since Ronald Reagan have done and determine what modifications, if any, are necessary. ${ }^{90}$ Second, HHS could change or permanently rescind the rules by promulgating new ones-but such a step would take time. HHS would need to follow the informal rulemaking requirements to ensure that no procedural deficiencies could open the new rules to legal challenge. Courts tend to be less deferential to agencies when reviewing regulatory changes created without a change in circumstances, as explained in Part III.A.3. Therefore, if the new administration chooses this approach, it should be careful to supply a reasoned analysis of why it believes the new agency interpretation is necessary.

Perhaps the most assertive recent invocation of executive power in the health care context is the Bush Administration's August 17, 2007, SCHIP directive. CMS issued the directive in the form of a letter to State Health Officials (SHO) limiting their discretion to set income eligibility caps for families whose kids participate in the Children's Health Insurance Program. ${ }^{91}$ Before covering children in families earning above $250 \%$ of the federal poverty limit (FPL), states must 1) prove that they have covered at least $95 \%$ of children below $200 \%$ of the FPL; 2 ) ensure that private coverage of these children has not decreased by more than "two percentage points over the five-year period"; ${ }^{92}$ 3) require a twelve-month waiting period for children coming off private coverage; and 4) impose new cost-sharing requirements. ${ }^{93}$

O’NEILL INSTITUTE FOR NATIONAL AND GLOBAL HEALTH LAW

GEORGETOWN LAW | 600 NEW JERSEY AVENUE NW | WASHINGTON, DC 20001 www.oneillinstitute.org 
Several states, including California, Kentucky, Oklahoma, and New York, have filed suit against HHS, claiming that the department has violated the Social Security Act and subsequent amendments that govern the Medicaid program. ${ }^{94}$ The Government Accountability Office (GAO) and Congressional Research Service (CRS) have issued separate reports questioning the legality of the Bush Administration's directive. ${ }^{95}$ Even though several members of Congress have drafted legislation to override it, the new administration has a few options at its disposal to revoke the August 17, 2007, directive, as well as set new policy for the SCHIP program. In fact, President Obama issued a Presidential Memorandum on February 4, 2009, requesting that the Secretary of the Department of Health and Human Services immediately withdraw the August 17 letter and implement SCHIP without the requirements it imposed. ${ }^{96}$ This memorandum represents one of the first instances of President Obama's using his executive authority to influence health policy.

\section{G. Build On the Federal Employees Health Benefits Program}

President Obama and Senator McCain both proposed policies for ensuring access to group coverage for those with pre-existing conditions who find it difficult to buy policies on the individual market. One option that has been mentioned as a potential springboard is the Federal Employees' Health Benefits Program (FEHBP). This popular program covers approximately 8 million people, including members of Congress, making it the largest employer-sponsored health insurance program in the country. ${ }^{97}$ Beneficiaries may choose between fee-for-service plans and HMOs, with $70 \%$ opting for the former. ${ }^{98}$ FFS policies are experience-rated, meaning that premiums are calculated based on "average service expenditures, administrative costs, and profits." U9 Unlike many other government programs, however, the statute governing FEHBP gives the Office of Personnel Management (OPM) enormous discretion to run the program. ${ }^{100}$ The statute grants OPM the power to negotiate benefits packages and premiums annually with plans. ${ }^{101}$ In addition, OPM has the authority to suggest ways for plans to contain costs as they craft their proposals and premium requirements. ${ }^{102}$

OPM has kept costs down compared to the other large purchasers ${ }^{103}$ by using two mechanisms to compel competition among the dozens of participating insurers. First, the basic construct of FEHBP forces plans to compete with one another on the benefits offered. Even though OPM does not define a specific benefit package, it requires a core baseline of services that all plans must provide. Every plan, therefore, can build its own benefit package to cater to the population it hopes to attract. Second, the statute requires that premiums "reasonably and equitably" reflect the cost of the benefit packages provided through FEHBP. ${ }^{104}$ The statute grants OPM the authority not only to adjust premiums, but also to place any remaining balances in the reserve funds when they prove too high. ${ }^{105}$

One option for President Obama is to invoke executive orders and memoranda to memorialize many of OPM's practices. Because it operates more like a private employer than a public program, many of the cost-saving programs and other policies are not formally noted and available for public distribution. Especially given that OPM negotiates annually with plans, the shelf life for these ideas may be relatively short. President Obama could use executive tools to formalize many of these "best practices" for private insurers participating in other federal programs (i.e., Medicare, Medicaid, etc.). To ensure the broadest reach for these policies and to

O’NEILL INSTITUTE FOR NATIONAL AND GLOBAL HEALTH LAW

GEORGETOWN LAW | 600 NEW JERSEY AVENUE NW | WASHINGTON, DC 20001 www.oneillinstitute.org 
promote consistency across departments, the new administration should use directives such as executive orders or memoranda, rather than departmental letters.

Another question is how much the Obama Administration could experiment with expanding the FEHBP. During the campaign, the President proposed the creation of a new public plan, the National Health Insurance Exchange, through which small businesses and individuals could purchase insurance benefits similar to those offered in the FEHBP. ${ }^{106}$ The statute provides no discretion to the OPM to replicate or open the program to populations beyond federal employees, their beneficiaries, and retirees. In order to allow others to participate in the program or a similar one, either by paying $100 \%$ of their own coverage or some other cost-sharing scheme, Congress would have to pass legislation. If the Obama Administration wishes to test a program that allows non-federal employees to participate, it would have to seek statutory authority even for a demonstration project that would apply to a limited group of people on a temporary basis. In 1999, for example, Congress passed legislation creating a 3-year demonstration project run jointly by the Department of Defense and OPM for Tricare beneficiaries. ${ }^{107}$ Once the President receives the authority, the contracting and negotiating power in Chapter 89 provides enormous opportunity to test various policies, accumulate information about what works and what does not, and craft more thoughtful proposals for more permanent and broad-based changes.

\section{H. Examples of Policies That Require Legislative Enactment}

Even though a President has significant executive authority to make policy changes, his actions must adhere to the statutory language provided by Congress. Some of the health reform ideas proposed by President Obama and Senator McCain would require new legislation because the U.S. Code either does not provide the President the necessary authority, or it limits his discretion. This section identifies two areas that would require congressional action: tax proposals and selling insurance across state lines. It also reminds us that the President's authority to reform health care is not boundless.

The majority of health reform plans include some adjustment or revision of federal tax laws. Changing tax policies - by offering new tax credits, modifying the currently favorable treatment of employer-sponsored insurance, or eliminating various rules - would require legislative action. The Constitution places the power to lay taxes solely in the legislative branch. ${ }^{108}$ Therefore, the President may not initiate changes to the tax structure, though he may obviously encourage Congress to do so.

During the campaign, Senator McCain offered a proposal to allow insurers to sell insurance across state lines in hopes of increasing competition and offering consumers greater choice. Such a move would require federal preemption legislation. States have been the traditional regulators of health insurance, as Congress explicitly recognized in $1945 .{ }^{109}$ Even though most states have some similar basic standards, there is significant variation in many of their requirements, including access rules and types of benefits required. ${ }^{110}$ Since the 1974 enactment of the Employee Retirement Income Security Act (ERISA), the federal government has become increasingly involved in regulating the benefits health insurance companies offer under employer-sponsored health plans. ERISA exempted private sector self-insured plans from state regulation. In addition, the Consolidated Omnibus Budget Reconciliation Act (COBRA) of 1986, and the Health Insurance Portability and Accountability Act (HIPAA) of 1996, provided

O’NEILl INSTITUTE FOR NATIONAL AND GLOBAL HEALTH LAW

GEORGETOWN LAW | 600 NEW JERSEY AVENUE NW | WASHINGTON, DC 20001 www.oneillinstitute.org 
additional consumer protections applicable to all private insurers. Despite this "floor" of federal rules, many insurance requirements still vary across states. Because insurers must comply with the laws of every state in which they operate, Congress would have to pass legislation explicitly preempting state regulatory authority. Specifically, federal legislation would be necessary to allow insurers to forgo some of the state rules so they could sell the same product across state lines. $^{111}$

\section{Limitations on Executive Authority}

There are numerous ways to reform health care through the administrative process. Yet the bedrock system of checks and balances ensures that executive authority is not boundless. Even though the executive branch has grown in size, political aggressiveness, and policy impact, there are significant limitations on what President Obama can do without congressional approval.

Article II, Section 1 of the Constitution, the "Vesting Clause," is the starting point for understanding these constraints. It entrusts the authority to run the executive branch in one individual - the President. ${ }^{112}$ Even though there is significant academic debate about how much power the President can exercise over the agencies (particularly the independent ones), ${ }^{113}$ recent administrations have shown that the President ultimately controls the policy and political agenda for the executive branch. ${ }^{114}$ In addition, the Constitution explicitly rests responsibility with the President for implementing Congress's legislative directives. Nevertheless, by dictating that the President "take Care that the Laws be faithfully executed," 115 the framers of the Constitution reminded the nation that the President's power to implement statutes is conditioned by the requirement that he or she adhere to Congress's intent as memorialized by the statutory language.

From stage right enters the judiciary. Courts play a critical role in making sure that the President does not overstep the interpretive power delegated by Congress and limited by the Constitution. The federal courts referee where Congress's directives end and the President's discretion begins. Indeed, during the last thirty years, the courts have imposed procedural and substantive constraints that limit the ability of agencies to disregard the will of Congress. It is often difficult, however, to reconcile legislative intent with the interpretive latitude provided to the President, particularly because Congress often does not clearly articulate its intentions. This tension has spawned thousands of pages of case law on the subject of judicial review.

This section explains and discusses these legal doctrines to help policymakers understand the limitations of reforming health care through the administrative process. It also analyzes the budgetary and political constraints on executive authority from both the legal and policy perspectives. Because history is often the best guide, Part III ends by providing statistics and examples of times when Congress has aggressively responded to the President's use of administrative tools.

\section{A. Judicial Review of Administrative Tools}

Chevron, Skidmore-Mead, State Farm, and Youngstown. These case names are commonplace among lawyers because they provide the legal boundaries that limit the executive branch's authority. These cases also are critically important to health policymakers so they can determine

O’NEILL INSTITUTE FOR NATIONAL AND GLOBAL HEALTH LAW

GEORGETOWN LAW | 600 NEW JERSEY AVENUE NW | WASHINGTON, DC 20001 www.oneillinstitute.org 
whether their proposals that rely not on Congress, but on administrative tools, encroach on the legislature's power to make law and on the judiciary's power to "say what the law is."116 The goal of this section is to assess the state of the law for both the legal and non-legal audience in the health policy community.

\section{Chevron: Statutory Interpretation}

We start with the iconic administrative law case, Chevron, which courts use to evaluate the propriety of an agency's interpretation of statutes. Trumpeted as one of the most important public law cases of the twentieth century, the Chevron Court held that when legislative language is ambiguous, courts should defer to an agency's "reasonable" interpretations of the statutory text. $^{117}$ The Supreme Court provided a now famous two-step inquiry. First, courts should determine "whether Congress has directly spoken to the precise question at issue."118 If, in other words, Congress's intent is unambiguously clear, then the agency must follow Congress's directive. If, on the other hand, Congress has not spoken directly to the precise question at issue (i.e., the statute is silent or ambiguous), it is for the federal courts to determine whether the agency's interpretation of the statute is reasonable. An agency's construction of a statute will stand - even if a court disagrees with it - as long as it is deemed reasonable. ${ }^{119}$ The lesson for the Obama Administration is that it must be mindful of not veering too far from the statutory language when it implements provisions of the MMA and other laws.

The Supreme Court emphasized two reasons for its groundbreaking holding: agency expertise and political accountability. In explaining its decision, the Court signaled that presidential involvement in agency decision-making counseled for a strong form of deference:

While agencies are not directly accountable to the people, the Chief Executive is, and it is entirely appropriate for this political branch of the Government to make such policy choices-resolving the competing interests which Congress itself either inadvertently did not resolve, or intentionally left to be resolved by the agency charged with the administration of the statute in light of everyday realities. $^{120}$

\section{Skidmore-Mead: Sub-Regulatory Guidance}

There are numerous situations, however, in which there is no indication that Congress intended to delegate authority to the executive branch to interpret the statute through regulations and other administrative tools that have the force of law. ${ }^{121}$ Nevertheless, agencies often need to create policies, such as through sub-regulatory guidance as described in Part I, to flesh out the details of a program when notice and comment rulemaking is impractical. An example of such a situation is CMS's August 17, 2007, letter restricting SCHIP coverage, as discussed above. Agencies also can rely on these vehicles for implementing day-to-day decisions in Medicare, Medicaid, and other complex programs. The Supreme Court has held that in such circumstances, it will accord a relatively weaker standard of deference to the agency that is "proportional to [the agency's] power to persuade.” 122 Known as Skidmore-Mead deference, this second standard provides more rigorous review of agency action than Chevron does.

O’NEILl INSTITUTE FOR NATIONAL AND GLOBAL HEALTH LAW 
An agency must prove three things: first, that its interpretation is thorough, logical, and accords with expert views; second, that its interpretation follows from the agency's earlier interpretations of the statute; and third, that other sources of weight support the interpretation. ${ }^{123}$ In short, under the Skidmore-Mead deference regime, the courts delve more deeply into the permissibility of an agency's interpretation of a statute than they do under Chevron. The Court recognized that the executive branch must often make decisions that Congress could not have foreseen, and that the agencies' expertise warrants some deference. ${ }^{124}$ Nevertheless, questions remain about the level of deference certain forms of sub-regulatory guidance (e.g., publications on agency web pages) should receive. Time and litigation will eventually provide the answers.

\section{State Farm: Regulatory Changes}

The Supreme Court has indicated, however, that courts should look carefully at changes to existing regulations. "An agency's view of what is in the public interest may change, either with or without a change in circumstances. But an agency changing its course must supply a reasoned

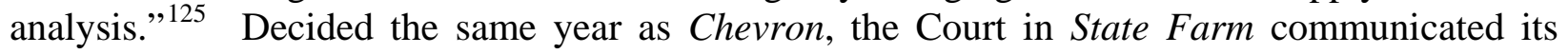
frustration with the Reagan Administration's decision to rescind a safety rule for seatbelts despite the lack of change in external circumstances other than the election of a new president. Since then, the Supreme Court has acknowledged in a number of health care cases that courts should limit the deference provided to agency interpretations that conflict with previously-held views. $^{126}$

When a court reviews an agency's decision to revoke or modify a regulation, it applies the standard for reviewing challenges to new rules: a court may set aside a rule if it is "arbitrary and capricious." ${ }^{127}$ Put more plainly, an agency must offer a rational explanation for its policy change and show that it accounted for the relevant facts and factors. ${ }^{128}$ Even though the standard of review is the same for new and modified rules, satisfying this standard may be more difficult when the data on which the agency relied has not changed. As the Court explained:

Normally, an agency rule would be arbitrary and capricious if the agency has relied on factors which Congress has not intended it to consider, entirely failed to consider an important aspect of the problem, offered an explanation for its decision that runs counter to the evidence before the agency, or is so implausible that it could not be ascribed to a difference in view or the product of agency expertise. $^{129}$

State Farm review, therefore, is critically important for President Obama as he considers regulatory changes. If the new administration chooses to overturn some of President Bush's Medicaid or other regulations, it must anchor its explanation in data and facts that reveal a changed environment.

\section{Youngstown: Executive Orders}

Finally, a president often initiates policies through executive orders. One example is President Clinton's order requiring insurers to comply with patient protection requirements in the FEHBP. The Supreme Court has created a particular standard of judicial review for determining when an executive order has strayed beyond the President's authority. In Youngstown Sheet \& Tube Co.

O’NEILL INSTITUTE FOR NATIONAL AND GLOBAL HEALTH LAW

GEORGETOWN LAW | 600 NEW JERSEY AVENUE NW | WASHINGTON, DC 20001 www.oneillinstitute.org 
v. Sawyer, a seminal post-World War II case, the Supreme Court held that executive authority to issue an order "must stem either from an act of Congress or from the Constitution itself.",130

To help courts analyze the scope of presidential power, the Court provided a three-part framework. ${ }^{131}$ First, if the President has acted pursuant to express or implied statutory authority, then his "authority is at its maximum" and is "supported by the strongest of presumptions and the widest latitude of judicial interpretation."132 Second, if Congress has neither delegated nor denied authority to the President, then he must rely "upon his own independent powers, but there is a zone of twilight in which he and Congress may have concurrent authority, or in which its distribution is uncertain." 133 Finally, if the President's order contradicts Congress's "express or implied will," his authority is at its lowest ebb. ${ }^{134}$ Courts will uphold an executive order in such circumstances only when the President's authority is based on a constitutional grant of exclusive power. $^{135}$

\section{B. Constraints Involving Appropriations}

Appropriations constraints also may limit a president's authority to act unilaterally. The key question is how much latitude a president has to determine health care spending priorities once Congress has made the requisite appropriations. The President and agency officials are obligated to follow congressional directives in statutory text. But the executive branch usually makes the vast majority of spending decisions pursuant to lump-sum appropriations by Congress.

The Supreme Court provided clear guidance on this issue in Lincoln v. Vigil. The Court held that agency spending decisions of a lump-sum appropriation are unreviewable in court. ${ }^{136}$ In laying out its rationale for the ruling, the Court emphasized the importance of permitting flexibility and deferring to agency expertise regarding the numerous policies and issues that must be balanced:

The allocation of funds from a lump-sum appropriation is [an] administrative decision traditionally regarded as committed to agency discretion. After all, the very point of a lump-sum appropriation is to give an agency the capacity to adapt to changing circumstances and meet its statutory responsibilities in what it sees as the most effective or desirable way. ${ }^{137}$

The Supreme Court further noted that Congress could only use explicit statutory text to bind agencies to particular spending decisions. "[I]ndicia in committee reports and other legislative history as to how funds should or are expected to be spent do not establish any legal requirements on the agency." "138 Obviously, the President and his agency heads run political risks by ignoring legislative history and other indications by Congress that convey how it wishes the money to be spent. Refusing to follow these expressions, however, does not violate the law.

President Obama will soon need to decide how he wishes his agencies to treat such legislative requests or suggestions. In early 2008, former President George W. Bush issued an executive order directing agencies not "to commit, obligate, or expend funds for any earmark" in a nonstatutory source. $^{139}$ In so doing, former President Bush took the discretionary principles of Lincoln $v$. Vigil one step further by ordering employees not to comply with earmark requests in legislative reports, letters from Members of Congress, or any other materials other than the explicit statutory text. ${ }^{140}$ It is too early to tell what impact the executive order will have. One

O’NEILL INSTITUTE FOR NATIONAL AND GLOBAL HEALTH LAW

GeORgETOWN LAW | 600 NEW JERSEY AVENUE NW | WASHINGTON, DC 20001 www.oneillinstitute.org 
obvious consequence may be that Congress increases use of explicit funding restrictions in appropriations legislation, including those involving health care programs. The order goes against the longstanding tradition that agencies should at least consider congressional spending requests in committee reports and joint explanatory statements prepared by conference committees. ${ }^{141}$ If President Obama retains the order, it is unlikely that a court will find it unlawful, particularly given the Supreme Court's significant deference in Lincoln to agency spending decisions.

\section{Legislative Constraints: Congressional Review Act}

The final question is how Congress can limit a President's executive authority to reform health care. The starting point is Congress's primary function - passing legislation. As discussed above, a significant source of the President's power comes from the authority that the legislative branch delegates through statutory text. Because Congress has increasingly delegated extensive power to flesh out the details of federal programs - which can be just as significant as the authorization itself - presidents have been able to take unilateral action much more often, particularly during the last thirty years. ${ }^{142}$ Within this expanding sphere of power, presidents can utilize the many administrative tools available to shape policy.

But delegation is mostly a positive concept; it focuses on the power granted rather than limitations placed on authority. The flipside is the negative act. Specifically, how could Congress undo the President's use of executive authority? Congress may limit agencies' discretion through a number of processes, including appropriations bills. Perhaps the most significant tool available is the Congressional Review Act (CRA). ${ }^{143}$ Enacted in 1996, the Act requires agencies to submit all rules to Congress before they can take effect. It allows Congress to pass a joint resolution disapproving of regulations issued by agencies, which the President must sign before the resolution takes effect. ${ }^{144}$ The CRA also provides expedited procedures for Congress to consider and disapprove of rules. For most rules, Congress has 60 days from when it receives the rule to start the joint resolution process. ${ }^{145}$ Once Congress enacts the resolution, "the agency may not reissue either that rule or any substantially similar one, except under authority of a subsequently enacted law."146

The question then is: how often has Congress successfully reversed regulations and other directives by the executive branch? Congress has overturned only one rule under the CRA -- a Clinton Administration ergonomics regulation in 2001. That should be unsurprising: garnering a two-thirds vote in each chamber to overturn a presidential directive (assuming the president has vetoed Congress's first attempt) is extraordinarily difficult. Anecdotal evidence reveals that legislators from 1940 to 1970 were equally unsuccessful at stopping Presidents' efforts to create policy unilaterally. ${ }^{147}$

O’NEILl INSTITUTE FOR NATIONAL AND GLOBAL HEALTH LAW 


\section{Conclusion}

As the Obama Administration crafts key policy and reform proposals for the coming years, health reform is a priority. The executive branch has the power to create, shape, and promote policy, including in health care. This authority is replete with legal issues steeped in both constitutional and statutory law, as well as the history of governing our nation. This paper describes ways that the President can work within constitutional and statutory boundaries to implement health reform.

While this paper does not purport to recommend particular uses of that executive authority, or to take a position on whether executive authority should be used expansively or sparingly, it analyzes the contours of the President's executive authority, and applies it to policy proposals identified by key players in the health reform debate. Specifically, this paper discusses administrative strategies to: (1) expand Medicaid and the State Children's Health Insurance Program (SCHIP) coverage through section 1115 waivers; (2) test quality initiatives through Medicare demonstration authority; (3) expand health information technology; (4) allow drug reimportation and experiment with contracting power under Medicare; (5) enhance patient protections and private coverage requirements; (6) lift coverage restrictions on Medicaid and SCHIP; and (7) build on the health insurance program for federal employees. While President Obama has already taken steps toward implementing his agenda, more options are available to achieve the Administration's policy goals.

\footnotetext{
* Law Clerk, Hon. Thomas B. Griffith, U.S. Court of Appeals for the D.C. Circuit; J.D., Yale Law School, 2008. I would like to thank Paul Begala, Benjamin Berkman, Melanie Bostwick, Sheila Burke, Phil Caplan, Brian Carey, Elenora Connors, Jack Ebeler, Liz Fowler, Michael Gottesman, Sandy Han, Katherine, Hayes, Mark Hayes, Sara Hoverter, Chris Jennings, Jeanne Lambrew, Benjamin Lawsky, John Monahan, Shiva Nagaraj, David Nexon, Luis Rodriquez, Dean Rosen, Stacey Sachs, Jacqueline Scott, Tim Westmoreland, and Lisbeth Zeggane for generous feedback and valuable advice. I am grateful to Larry Benn for his meticulous line edits. All views and errors are mine alone.

${ }^{1}$ Terry M. Moe \& William G. Howell, “The Presidential Power of Unilateral Action,” Journal of Law, Economics, and Organization, 15, no. 1 (1999): 132-179, at 158.

2 H. C. Reyla, Presidential Directives: Background and Overview, Congressional Research Service Report to Congress (Aug. 9, 2007), at 2.

${ }^{3}$ T.J. Halstead, Executive Orders: Issuance and Revocation, Congressional Research Service Report to Congress, RS20846 (Mar. 19, 2001).

${ }^{4}$ U.S. CONST. art. II, § 3.

${ }^{5}$ Reyla, supra note 2, at 5

${ }^{6}$ Proclamation No. 17, 12 Stat. 1268 (1863).

${ }^{7}$ Reyla, supra note 2, at 5.

${ }^{8}$ Moe \& Howell, supra note 1, at 155; See also Halstead, supra note 3; House Committee on Government Operations, Executive Orders and Proclamations: A Study of a Use of Presidential Powers, 85th Cong., $1^{\text {st }}$ sess., 1957.

${ }^{9}$ Federal Register Act, 44 U.S.C. $§ 1505$.

${ }^{10} 5$ U.S.C. $\S 551(4)$.

115 U.S.C. $\$ 553(\mathrm{~b})$.

${ }^{12}$ Halstead, supra note 3, at 2.

${ }^{13}$ Id.
}

O’NEILl INSTITUTE FOR NATIONAL AND GLOBAL HEALTH LAW GEORGETOWN LAW | 600 NEW JERSEY AVENUE NW | WASHINGTON, DC 20001 www.oneillinstitute.org 
${ }^{14} 44$ U.S.C. § 1505(a); see also Halstead, supra note 3, at 2.

15 T.J. Halstead, Presidential Signing Statements: Constitutional and Institutional Implications, Congressional Research Service Report to Congress, RL33667 (Sept. 17, 2007), at 1.

${ }^{16}$ Id. at 3-4.

${ }^{17}$ Id. at 22.

${ }^{18}$ Moe \& Howell, supra note 1 , at 160.

${ }^{19}$ Edwin Park, "An Examination of the Wyden-Bennett Health Reform Plan: Key Issues in a New Approach to Universal Coverage," Center on Budget and Policy Priorities, available at http://www.cbpp.org/9-24-08health.htm (last visited December 15, 2008).

${ }^{20} 42$ U.S.C. 1315. The provision's language has changed very little since its enactment. It currently reads: “(a) In the case of any experimental, pilot, or demonstration project which, in the judgment of the Secretary, is likely to assist in promoting the objectives of title... XIX ... in a State or States (1) the Secretary may waive compliance with any of the requirements of section ...1902, as the case may be, to the extent and for the period he finds necessary to enable such State or States to carry out such project...” The original Section 1115 statute was passed as Pub. L. No. 87-543, 76 Stat. 192, available at http://www.ssa.gov/OP_Home/ssact/title11/1115.htm (last visited December 15, 2008).

${ }^{21}$ Kaiser Commission on Medicaid and the Uninsured, Section 1115 Waivers in Medicaid and the State Children's Health Insurance Program: An Overview (July 20, 2001), at 3, available at http://www.kff.org/medicaid/loader.cfm?url=/commonspot/security/getfile.cfm\&PageID=13881 (last visited December 15, 2008).

${ }^{22} I d$.

23 "Under Section 1115, the Department of Health and Human Services is given latitude, subject to the requirements of the Social Security Act, to consider and approve research and demonstration proposals with a broad range of policy objectives. The Department desires to facilitate the testing of new policy approaches to social problems. ... In order to ensure a sound, expeditious and open decision-making process, the Department will be guided by the policies and procedures described in this statement in accepting and reviewing proposals submitted pursuant to section 1115.” Medicaid Program: Demonstration Proposals Pursuant to Section 1115(a) of the Social Security Act; Policies and Procedures, 59 Fed. Reg. 49,249, (September 27, 1994).

24 "[T] sufficient duration to give new policy approaches a fair test. The duration of waiver approval should be congruent with the magnitude and complexity of the project (for example, large-scale statewide reform programs will typically require waivers of five years) ....” Id.

25 "The Department will assess cost neutrality over the life of a demonstration project, not on a year-by-year basis, since many demonstrations involve making 'up-front' investments in order to achieve out-year savings.” Id.

${ }^{26}$ Thompson emphasized that the administration wanted "to give governors the flexibility they need to expand insurance coverage to more Americans through innovative approaches, including the kind of health insurance options available in the private sector.” Department of Health and Human Services, HHS to Give States New Options for Expanding Health Coverage: New Initiative Promotes State Innovations to Expand Access for the Uninsured, Press Release dated August 4, 2001, available at http://www.hhs.gov/news/press/2001pres/20010804.html (last visited December 15, 2008).

${ }^{27}$ First, it encourages states to explore ways to increase the number of individuals covered through the Medicaid program by limiting benefits and increasing cost sharing. Second, it requires states to integrate with some form of private health insurance scheme in Medicaid's public financing scheme. Third, it targets beneficiaries earning salaries less than 200 percent of the federal poverty level (FPL). J. M. Ryan, National Health Policy Forum, 1115 Ways to Waive Medicaid and SCHIP Rules (Jun. 13, 2002), at 3, available at http://www.nhpf.org/pdfs_ib/IB777_1115Waivers_6-13-02.pdf (last visited December 16, 2008).

${ }^{28}$ E. P. Baumrucker, Medicaid and SCHIP Section 1115 Research and Demonstration Waivers, Congressional Research Service Report to Congress (Mar. 8, 2007), at 1

${ }^{29} \mathrm{Id}$.

${ }^{30} 42$ U.S.C. 1936a(a)(10)(A)(i) (2008).

${ }^{31}$ Alexander v. Choate, 469 U.S. 287 (1985).

3242 U.S.C. $\S 1395 b-1(a)(1)(A)(2008)$.

3342 U.S.C. $\S 1395 b-1(a)(1)(A)-(K)(2008)$.

O'NeILl INSTitute FOR NATIONAL AND GLOBAL HEALTH LAW GEORGETOWN LAW | 600 NEW JERSEY AVENUE NW | WASHINGTON, DC 20001 www.oneillinstitute.org 
34 United States Government Accountability Office, Medicare Demonstration PPOs: Financial and Other Advantages for Plans, Few Advantages for Beneficiaries, Report to the Ranking Minority Member, Committee on Finance, U.S. Senate (September 2004), at 2; 42 U.S.C. § 1395b-1(a)(2) (2008).

3542 U.S.C. § 1395b-1(b) (2008).

${ }^{36}$ In authorizing a demonstration project, however, Congress sometimes references and incorporates the existing section 222 waiver authority in legislation. Piperreport: Medicaid, Medicare, Pharma, and more, available at http://www.piperreport.com/archives/categories/72.html (last visited December 16, 2008).

${ }^{37}$ Baumrucker, supra note 28 at 7.

38 Centers for Medicare and Medicaid Services, Department of Health and Human Services, Medicare Demonstrations, available at http://www.cms.hhs.gov/DemoProjectsEvalRpts/MD/list.asp\#TopOfPage (last visited December 15, 2008).

${ }^{39}$ Centers for Medicare and Medicaid Services, Department of Health and Human Services, Medicare Physician Group Practice Demonstration, available at

http://www.cms.hhs.gov/DemoProjectsEvalRpts/downloads/PGP_Fact_Sheet.pdf (last visited December 15, 2008).

${ }^{40}$ Centers for Medicare and Medicaid Services, Department of Health and Human Services, Rural Hospice

Demonstration Summary, available at

http://www.cms.hhs.gov/DemoProjectsEvalRpts/downloads/RMBH_Summary.pdf (last visited December 15, 2008).

${ }^{41}$ Centers for Medicare and Medicaid Services, Department of Health and Human Services, Medicare Fact Sheet, Help for Chronically Ill Beneficiaries: The Medicare Disease Management Demonstration, available at http://www.cms.hhs.gov/DemoProjectsEvalRpts/downloads/BIPAADM_Fact_Sheet.pdf (last visited December 15, 2008).

${ }^{42}$ Centers for Medicare and Medicaid Services, Department of Health and Human Services, Legislative History MMA \$646 - Medicare Health Care Quality Demonstration, available at http://www.cms.hhs.gov/DemoProjectsEvalRpts/downloads/MMA646_Legislation.pdf, (last visited December 15, 2008).

${ }^{43}$ R. Hillestad, et al., "Can Electronic Medical Record Systems Transform Healthcare? An Assessment of Potential Health Benefits, Savings, and Costs,” Health Affairs, 24, no. 5 (2005): 1103-1117, at 1103.

${ }^{44}$ HHS is in the process of coordinating the development of standards with a variety of private actors and federal agencies, as required by Congress in HIPAA. Medicare Payment Advisory Committee, "Report to the Congress:

New Approaches in Medicare,” (June 2004), at 173, available at http://www.medpac.gov/documents/June04_Entire_Report.pdf (last visited December 15, 2008).

45 Exec. Order No. 13,335, 69 Fed. Reg. 84 (April 30, 2004).

${ }^{46}$ See, e.g., Exec. Order 13,410, 71 Fed. Reg. 166 (August 22, 2006).

${ }^{47}$ Medicare Improvements for Patients and Providers Act of 2008,Pub. L. No. 110-275, 122 Stat. 2525 (2008). ${ }^{48} \mathrm{Id}$.

${ }^{49}$ Medicare Prescription Drug, Improvement, and Modernization Act of 2003, Pub. L. No. 108-173, 117 Stat. 2066 (2003); See also M. O. Leavitt, Sec. U.S. Dept of HHS, Pilot Testing of Initial Electronic Prescribing Standards Cooperative Agreements Required Under Section 1860D-(4) (e) of the Social Security Act as Amended by the Medicare Prescription Drug, Improvement, and Modernization Action (MMA) of 2003, available at http://www.cms.hhs.gov/EPrescribing/Downloads/E-RxReporttoCongress.pdf (last visited Dec. 16, 2008).

50 See U.S. Dept. Health and Human Services, Centers for Medicare and Medicaid Services, E-Prescribing Overview, available at http://www.cms.hhs.gov/EPrescribing/ (last visited Dec. 16, 2008).

${ }^{51}$ Pub. L. No. 110-275 (110 ${ }^{\text {th }}$ Cong.) 122 STAT. 2525, Sec. 132(b)(5)(B).

52 Pub. L. No. 110-275 (110 ${ }^{\text {th }}$ Cong.) 122 STAT. 2525, Sec. 132(a)(2)(A).

53 Dept. of HHS, Centers for Medicare and Medicaid Services, Electronic Health Records Demonstration, Demonstration Summary, 1-19 at

http://www.cms.hhs.gov/DemoProjectsEvalRpts/downloads/EHR_DemoSummary.pdf (last visited Dec. 16, 2008).

${ }^{54}$ Id. at 2.

${ }^{55} \mathrm{Id}$.

56 Id. at 6.

${ }^{57} \mathrm{Id}$. at 4 .

${ }^{58}$ Medicare Prescription Drug, Improvement, and Modernization Act of 2003, Pub. L. No. 108-173, 117 Stat. 2066 (2003).

5942 U.S.C. § 1395w-111(i) (2008).

O’NEILl INSTITUTE FOR NATIONAL AND GLOBAL HEALTH LAW GEORGETOWN LAW | 600 NEW JERSEY AVENUE NW | WASHINGTON, DC 20001 www.oneillinstitute.org 
6021 U.S.C. § 384(b) (2008).

6121 U.S.C. § 384(1)(1) (2008).

${ }^{62}$ R. Pear, “Administration Offers a Mixed View on Drug Imports,” New York Times, December 22, 2004.

6342 U.S.C. § $1395 \mathrm{kk}-1$ (2008).

${ }^{64} 42$ U.S.C. § 1395kk-1(a)(4)(A) \& (B) (2008).

${ }^{65}$ Legislative History, Page 758 (emphasis added).

${ }^{66} I d$.

${ }^{67} 42$ U.S.C. $\S 1395 \mathrm{w}-111(\mathrm{i})(2)(2008)$.

6842 U.S.C. § 1395kk-1(a)(4)(A) (2008).

${ }^{69}$ Centers for Medicare and Medicaid Services, "Durable Medical Equipment (DME) Medicare Administrative Contractor (MAC) Award General Fact Sheet," available at http://www.cms.hhs.gov/MedicareContractingReform/Downloads/DME_MAC_Awards_General_Fact_Sheet.pdf (last visited December 16, 2008).

${ }^{70}$ Executive Memorandum 8, The Health Care Consumer Bill of Rights and Responsibilities (1997). See also Exec. Order 13,040, 62 Fed. Reg. 14,773 (March 28, 1997); Exec. Order 13,056, 62 Fed. Reg. 39,415 (July 23, 1997).

${ }^{71}$ R. Pear, "Clinton to Punish Insurers Who Deny Health Coverage,” New York Times, July 7, 1998.

${ }^{72}$ James Bennet, "True to Form, Clinton Shifts Energies Back to U.S. Focus,” New York Times, July 5, 1998.

${ }^{73}$ Public L. No. 104-191 (Aug. 21, 1996).

${ }^{74}$ See, e.g., id., Sec. 707.

${ }^{75}$ Interim Rules for Health Insurance Portability for Group Health Plans, 62 Fed. Red. 16,894 (April 8, 1997).

${ }^{76}$ Application of HIPAA Group Market Portability Rules to Health Flexible Spending Arrangements, 62 Fed. Reg. 67,688 (December 29, 1997); Health Insurance Portability, 64 Fed. Reg. 57,520 (October 25, 1999).

${ }^{77}$ Final Regulations for Health Coverage Portability for Group Health Plans and Group Health Insurance Issuers Under HIPAA Titles I \& IV, 69 Fed. Reg. 78,720 (December 30, 2004).

${ }^{78}$ U.S. Department of Labor, "Bush Administration Announces Final Rules on Portability of Health Coverage," available at http://www.dol.gov/ebsa/newsroom/pr123004.html (last visited December 16, 2008).

${ }^{79}$ Final Regulations for Health Coverage Portability for Group Health Plans and Group Health Insurance Issuers Under HIPAA Titles I \& IV, 69 Fed. Reg. at 78721.

${ }^{80}$ Final Regulations for Health Coverage Portability for Group Health Plans and Group Health Insurance Issuers Under HIPAA Titles I \& IV, 69 Fed. Reg. 78722.

${ }^{81}$ Barack Obama and Joe Biden's Plan to Lower Health Care Costs and Ensure Affordable, Accessible Health Coverage for All, at http://www.barackobama.com/pdf/issues/HealthCareFullPlan.pdf (last visited December 15, 2008)

${ }^{82}$ See, e.g., Pub. L. No. 104-191, sec. 707 (Aug. 21, 1996).

${ }^{83}$ Medicaid Programs: Premiums and Cost Sharing, 73 Fed. Reg. 71,828 (Nov. 25, 2008). See also Robert Pear, "New Medicaid Rules Allow States to Set Premiums and Higher Co-Payments," New York Times (November 26, 2008). The rule implements provisions of the Deficit Reduction Act of 2005. Pub. L. No. 109-171, 120 Stat. 4.

${ }^{84}$ Medicaid Program: Elimination of Reimbursement Under Medicaid for School Administration Expenditures and Costs Related to Transportation of School-Age Children Between Home and School, 72 Fed. Reg. 73,635 (Dec. 28, 2007).

${ }^{85}$ Medicaid Program: Graduate Medical Education, 72 Fed. Reg. 28,930 (May 23, 2007).

${ }^{86}$ Medicaid Program: Coverage for Rehabilitative Services, 72 Fed. Reg. 45,201 (Aug. 13, 2007). Other policies have included: restricting federal reimbursement of case management services, including those for children in foster care, Medicaid Program; Optional State Plan Case Management Services, 72 Fed. Reg. 68,077 (Dec. 4, 2007); limiting Medicaid payments to state and locally run hospitals and other entities, Cost Limit for Government Providers Final Rule, 72 Fed. Reg. 29,748 (May 29, 2007); cutting the types of services that qualify for outpatient hospital services reimbursement, Revised Outpatient Clinic and Hospital Services Proposed Rule, (72 Fed. Reg. 55,158 (Sep. 28, 2007).); and providing other technical changes that could have a significant impact on the operation of the Medicaid program, Medicaid Provider Taxes Final Rule, 73 Fed. Reg. 9,685 (Feb. 22, 2008); Departmental Appeals Board Procedures Proposed Rule, 72 Fed. Reg. 73,708 (December 28, 2007). For a more comprehensive discussion about the effects of the Medicaid rules, see R. Rudowitx, "Medicaid: Overview and Impact of New Regulations," The Kaiser Commission on Medicaid and the Uninsured, \#7739 (Jan. 2008); E.J. Herz and V.K. Burrows, "Medicaid Regulatory Issues," Congressional Research Service, RL34764 (Nov. 26, 2008).

${ }^{87}$ R. Pear, "New Medicaid Rules Allow States to Set Premiums and Higher Co-Payments," New York Times, November 27, 2008, at A25.

O’NEILL INSTITUTE FOR NATIONAL AND GLOBAL HEALTH LAW GEORGETOWN LAW | 600 NEW JERSEY AVENUE NW | WASHINGTON, DC 20001 www.oneillinstitute.org 
${ }^{88}$ Congressional Budget Office, “Medicare, Medicaid, and SCHIP Administrative Actions Reflected In CBO’s Baseline” (Feb. 29, 2008), available at http://www.cbo.gov/budget/factsheets/2008b/medicaremedicaid.pdf (last visited December 15, 2008).

${ }^{89}$ A. Orris and J. Soloman, “Administration's Medicaid Regulations Will Weaken Coverage, Harm States, and Strain health Care System," Center on Budget and Policy Priorities (Mar. 4, 2008), available at http://www.cbpp.org/2-13-08health.pdf (last visited December 15, 2008).

${ }^{90}$ Exec. Order No. 12,291, 3 C.F.R. § 127 (1981 Comp.), 46 Fed. Reg. 13,193 (Feb. 17, 1981). S.R. Furlong, “The 1992 Regulatory Moratorium: Did it Make a Difference?,” Public Administration Review, 55, no. 3 (1995): 254262.

${ }^{91}$ Letter from D.G. Smith, Director of the Center on Medicare and Medicaid Operations, to State Health Officials, SHO \#07-001 (Aug. 17, 2007), available at http://www.cms.hhs.gov/smdl/downloads/SHO081707.pdf (last visited December 15, 2008). CMS also issued a clarifying letter. Letter from H.B. Kuhn, Deputy Administrator and Acting Director of the Center on Medicare and Medicaid Operations, to State Health Officials, SHO \#08-003 (May 7, 2008), available at http://www.ncsl.org/print/health/CMSUpdateSCHIPLetter.pdf (last visited December 15, 2008).

${ }^{92}$ Smith, supra note 91.

${ }^{93} \mathrm{Id}$.

${ }^{94}$ Kentucky v. Dep’t of Health \& Human Serv., Civ. No. 01: 08-00363 (D.D.C. 2008), available at http://www.nasmd.org/issues/docs/AmendedComplaint0208.pdf (last visited December 15, 2008).

${ }^{95}$ Statement of D.K. Shah, Managing Association General Counsel, Gov't Accountability Office, "Congressional Review Act: Applicability to CMS Letter on State Children's Health Insurance Program," testifying before the Subcomm. on Health, Comm. on Energy and Commerce, House of Representatives GAO-08-785T (May 15, 2008), available at http://www.gao.gov/new.items/d08785t.pdf (last visited December 15, 2008); Memorandum from M. Rosenberg, Legal Specialist, Congressional Research Service, to Senator J.D. Rockefeller IV, “Applicability of the Congressional Review Act to a CMS Guidance Document Regarding Statutory and Regulatory Requirements to be Used in Reviewing State Requests to Extend Eligibility Under SCHIP” (Jan. 10, 2008), available at http://rockefeller.senate.gov/press/CRSMemo01102008.pdf (last visited December 15, 2008).

${ }^{96}$ Presidential Memorandum of February 4, 2009: State Children’s Health Insurance Program, 74 Fed. Reg. 6,347 (Feb. 6, 2009).

${ }^{97}$ B. English, "Health Benefits for Members of Congress,” Congressional Research Service RS21982 (Sept. 25, 2007).

${ }^{98}$ Gov’t Accountability Office, “Federal Employees’ Health Plans: Premium Growth and OPM’s Role in Regulating Benefits,” Report to the Subcomm. on International Security, Proliferation, and Fed. Services, Comm. on

Governmental Affairs, U.S. Senate, GAO-03-236 (Dec. 2002), at 7, available at

http://www.gao.gov/new.items/d03236.pdf. (last visited December 15, 2008).

${ }^{99} I d$.

100 Chapter 89 in Title V of the U.S. Code

101 5 U.S.C. § 8902 (2007).

${ }^{102}$ See Gov't Accountability Office, "Federal Employees' Health Plans: Premium Growth and OPM's Role in Regulating Benefits," supra note 98, at 18 (endnote 122).

${ }^{103}$ Gov't Accountability Office, "Federal Employees Health Benefits Program: Premium Growth Has Recently Slowed, and Varies Among Participating Plans," Report to the Ranking Minority Member, Subcomm. on Oversight of Gov't Management, the Fed. Workforce, and the D.C., Comm. on Homeland Security and Governmental Affairs, U.S. Senate, GAO-07-141 (Dec. 2006), available at http://www.gao.gov/new.items/d07141.pdf. (last visited December 15, 2008).

104 5 U.S.C. § 8902(i) (2007).

${ }^{105}$ Gov't Accountability Office, supra note 103.

${ }^{106}$ National Active and Retired Federal Employees Association, "2008 NARFE Presidential Candidate Survey

McCain, Obama Respond to Questionnaire” (2008), available at

http://www.narfe.org/departments/home/articles.cfm?ID=1630 (last visted Dec. 15, 2008).

${ }^{107}$ National Defense Authorization Act for 1999, Pub. L. No. 105-261; Federal Employees Health Benefits Program and Department of Defense Demonstration Project Final Rule, 65 Fed. Reg. 35,259 (June 2, 2000); Federal Employees Health Benefits Program and Department of Defense Demonstration Project and Other Miscellaneous Changes Final Rule, 65 Fed. Reg. 36,382 (June 8, 2000).

${ }^{108}$ U.S. Const. art. I, § 8 (“The Congress shall have power to lay and collect taxes ... ”).

O’NEILl INSTITUTE FOR NATIONAL AND GLOBAL HEALTH LAW GEORGETOWN LAW | 600 NEW JERSEY AVENUE NW | WASHINGTON, DC 20001 www.oneillinstitute.org 
${ }^{109}$ The McCarran-Ferguson Act states that "the business of insurance ... shall be subject to the laws of the several States ...” 15 U.S.C. § 1012 (2007).

${ }^{110}$ M. Kofman and K. Pollitz, "Health Insurance Regulation by States and the Federal Government: A Review of Current Approaches and Proposals for Change,” Georgetown University Health Policy Institute (May 2006), at 1, available at http://www.allhealth.org/BriefingMaterials/HealthInsuranceReportKofmanandPollitz-95.pdf (last visited December 15, 2008.

${ }^{111}$ For a thorough analysis of a similar proposal, see id. at 8-9.

${ }^{112}$ U.S. CONST. art. II, § 1 ("The executive Power shall be vested in the President of the United States of America.").

113 P. Strauss, Presidential Rulemaking, Chicago-Kent Law Review 72 (1997): 965-986, at 965. R. V. Percival, "Presidential Management of the Administrative State: the Not-So-Unitary Executive," Duke Law Journal 51 (2001): 963-1013, at 963.

${ }^{114}$ E. Kagan, "Presidential Administration,” Harvard Law Review114 (2000-2001): 2245-2385 at 2248.

${ }^{115}$ U.S. CONST. art. II, § 3.

116 Marbury v. Madison, 5 U.S. (1 Cranch) 137 (1803).

${ }^{117}$ Chevron U.S.A., Inc. v. Natural Resources Defense Council, Inc., 467 U.S. 837 (1984).

${ }^{118} \mathrm{Id}$. at 842 .

${ }^{119} \mathrm{Id}$. at 843 .

${ }^{120} \mathrm{Id}$. at $865-66$.

${ }^{121}$ United States v. Mead, 533 U.S. 218, 237 (2001).

${ }^{122} I d$. at 235.

${ }^{123}$ Id. (quoting Skidmore et al. v. Swift \& Co., 323 U.S. 134, 140 (1944)..

124 "An agency's interpretation may merit some deference whatever its form, given the specialized experience and broader investigations and information available to the agency, and given the value of uniformity in its administrative and judicial understandings of what a national law requires.” Id. at 220 (quoting Skidmore v. Swift, 323 U.S. at 139).

${ }^{125}$ Motor Vehicle Manufacturers Ass'n v. State Farm Mutual Automobile Insurance Co., 463 U.S. 29,57 (1983).

${ }^{126}$ Kagan, supra note 114, at 2378; Good Samaritan Hosp. v. Shalala, 508 U.S. 402, 417-8 (1993); Pauley v. Bethenergy Mines, Inc., 501 U.S. 680, 698-99 (1991); Bowen v. Georgetown Univ. Hosp., 488 U.S. 204, 212-13 (1988). But see Rust v. Sullivan, 500 U.S. 173, 186-87 (1991).

1275 U.S.C. $\S 553$ (2000). See also State Farm, 463 U.S. 29, 42.

${ }^{128}$ State Farm, 463 U.S.29, 43.

${ }^{129} \mathrm{Id}$.

${ }^{130} \mathrm{Id}$. at 585.

${ }^{131}$ Youngstown Sheet \& Tube Co. v. Sawyer, 343 U.S. 579, 585 (1952).

${ }^{132}$ Id. at $635,637$.

${ }^{133}$ Id. at 636-37.

${ }^{134} \mathrm{Id}$.

${ }^{135}$ Id. at 637-38.

${ }^{136}$ Lincoln v. Vigil, 508 U.S. 182 (1993).

${ }^{137}$ Id. at192.

${ }^{138} I d$.

${ }^{139}$ Exec. Order. 13457 (signed January 29, 2008) 73 Fed. Reg. 6417 (February 1, 2008).

${ }^{140}$ Id.; see also T. J. Nicola \& T.J. Halstead, Earmarks Executive Order: Legal Issues, Congressional Research Service Report to Congress (Feb. 13, 2008), at 4.

${ }^{141}$ Nicola, Earmarks..., at i.

${ }^{142}$ Moe \& Howell, supra note 1, at 165. J. L. Fleishman \& A.H. Aufses, "Law and Orders: The Problem of Presidential Legislation,” Law and Contemporary Problems, 40, no. 3 (1976) 1-45, at 5; T.J. Lowi, The End of the Republican Era (University of Oklahoma Press, 1995).; G. Silverstein, Imbalance of Powers: Constitutional Interpretation and the Making of American Foreign Policy (New York: Oxford University Press, 1997).

${ }^{143}$ U.S.C. Chapter 8 (2007); See also R. S. Beth, Disapproval of Regulations by Congress: Procedure Under the Congressional Review Act, CRS Report, October 10, 2001.

144 R. S. Beth, Disapproval of Regulations by Congress: Procedure Under the Congressional Review Act, CRS Report, October 10, 2001.

${ }^{145} \mathrm{Id}$.

${ }^{146} I d$.

O’NEILl INSTITUTE FOR NATIONAL AND GLOBAL HEALTH LAW GEORGETOWN LAW | 600 NEW JERSEY AVENUE NW | WASHINGTON, DC 20001 www.oneillinstitute.org 
${ }^{147}$ Presidents Roosevelt, Truman, Kennedy, and Johnson issued numerous executive orders to chip away at the problem of racial discrimination. Despite their opposition, legislators found it difficult to pass legislation nullifying the orders. The only successful congressional response was the Russell Amendment, "which required congressional approval of all funds for agencies set up through executive order that remained for a over a year-a specific attempt to eliminate the Fair Employment Practices Committee, which had been created by Roosevelt's civil rights order." Yet presidents since Harry Truman found a way around this hurdle by relying on another statute, the 1946 Independent Offices Appropriations Act, to fund civil rights commissions. Therefore, history has shown that Congress, in the twentieth century, has had little success overturning policies created by the President through the administrative process. Moe and Howell, supra note 1, at 165, 176. 